\title{
Islands of Grass
}

By Trevor Herriot. Photography by Branimir Gjetvaj. 2017. Coteau Books. 224 pages, 39.95 CAD/USD, Cloth.

If you have always wanted to explore Grasslands National Park (GNP) in southern Saskatchewan but haven't managed to pull that off yet, get this book to see why you have to move it to the top of your 'Must See' list. But if you have managed to navigate across the vast ocean of Canadian prairie grain fields to visit that remarkable landscape, you should also get this book to remind yourself why that long, big-sky drive was worth it. Either way, Islands of Grass offers an accurate, visually stunning, and verbally inspirational portrayal of GNP and its sister native grasslands across the northern Great Plains.

I refer to GNP and sister native grasslands as separate entities; sadly, that is all too true. Less than $20 \%$ of the original native prairie grassland remains and less than $4 \%$ of that is in protective status. While we are quick to disparage overdevelopment and history of abusive land use in more heavily populated forested landscapes, especially in the east, the native prairie of western Canada actually constitutes the most ecologically reduced and imperilled of all major Canadian biomes.

But let's get back to celebrating it, which Islands of Grass is all about. At first glance it is tempting to treat this small, well constructed, and full colour volume as a 'coffee table' book. And it is, though much more as well. Gjetvaj's images are routinely wonderful and frequently breathtaking. I've had the good fortune of visiting GNP on three (far-too-short) occasions and the take-away feeling from those visits is demonstrably reflected in these images. Capturing the depth and size of prairie landscape in a photograph is really tough, as my innumerable lifeless attempts to do so document only too well. Somehow Gjetvaj achieves an almost threedimensional quality in many of his images. Scanning his landscape vistas in Islands of Grass, one can almost hear the meadowlarks singing.

And reading Herriot's text, you can almost smell the locoweed (Oxytropis), sagebrush (Artemisia), and dust -with perhaps a soupçon of bison poop! His words are as illustrative and evocative as the book's photography. This is not a traditional "natural history of..." book but, nonetheless, it contains an abundance of well researched (and referenced) information on the evolution, significance, and ecology of native grasslands. Its discursive presentation means that you have to dig a bit to pull it all together, but you will learn a lot about native grassland dynamics, even if you thought you already knew a good deal about the subject. Herriot delves deeply into how native grassland sounds and feels, into the magic of the place, and how it can provide a reasonably perceptive visitor with a better perspective on their place on this planet. It's quite remarkable, really.

Appropriately, the book is dedicated to the late George Ledingham. For decades he was the doggedly determined inspiration for a grasslands national park. Herriot gives him full credit for his pivotal role and nicely captures the personality of this important resident of the grasslands. A pillar of the prairie naturalist community, Ledingham was elected an Honorary Member of the Ottawa Field-Naturalists' Club largely for his work towards the establishment of GNP (see Canadian Field-Naturalist 127: 76-81, https://doi.org/10.22621/ cfn.v127i1.1414). It was disappointing and a bit surprising, however, not to see a photo of George in here, ideally out on the prairie, of course.

Islands of Grass employs insights into iconic prairie fauna such as American Bison (Bison bison), Blacktailed Prairie Dog (Cynomys ludovicianus), Kit Fox (Vulpes macrotis), sage grouse (Centrocercus sp.), and Burrowing Owl (Athene cunicularia) to describe and explain the nature, scope, and significance of change in this landscape. Not a lot of cheery news there, it must be said. Some, but not a lot. Accordingly, the conservation message is strong throughout the book. The ongoing important but currently losing battle to keep native prairie community pastures in public ownership, for example, receives considerable well-reasoned discussion and argument. It is not surprising to report that large scale agribusiness does not come off well in that discussion.

All this is expressed in Herriot's comfortable, unhurried, and discursive way, even if Chapter 5, "Possible Prairie", does seem to repeat the core conservation messages a bit too often. There is a tendency throughout to somewhat romanticize the conservation role of independent, multi-generational ranching and farming families, conclusions that seem a tad culturally biased.

Similarly, I don't think a negative word is expressed regarding Aboriginal activities, historic or contemporary, in regards to prairie land use or cultural attitudes. One need only to visit the remarkable Head-SmashedIn Buffalo Jump World Heritage Site in Alberta (another insightful place concerning the natural and human history of the Canadian prairies), however, to appreciate that land management by prairie people has always been directed by what was seen to be in their own best interest. Just like people everywhere. I would have liked to see the message more strongly expressed that effective conservation in the grasslands (or anywhere) is not driven by cultural affiliations or altruism but is fundamentally grounded in enlightened self-interest.

My favourite line in the book has got to be "whether you are a microbe or a buffalo, all flesh is grass" (p. 31). That pretty much makes the point, doesn't it? It all comes back to the grass, both in the prairie and in this informative and inspiring book.

DANIEL F. BRUNTON

Ottawa, ON, Canada 